Article

\title{
The Influence of the Role Positioning of Investment Institutions on the Value of Start-Up Enterprises from the Perspective of Network
}

\author{
Tong Liu ${ }^{1, *}$, Shiyou $Q u^{1}$ and Christopher M. Scherpereel ${ }^{2}$ \\ 1 School of Management, Harbin Institute of Technology, Harbin 150001, China; qushiyou@hit.edu.cn \\ 2 The W.A. Franke College of Business, Northern Arizona University, Flagstaff, AZ 86001, USA; \\ chris.scherpereel@nau.edu \\ * Correspondence: liut@hit.edu.cn
}

Received: 12 December 2019; Accepted: 7 January 2020; Published: 8 January 2020

\begin{abstract}
Based on the relevant data of joint investment from 2013 to 2017, this paper constructs a multivariate regression model, introduces the social network analysis method and the Bonacich Power Index to quantify the network attribute indicators of investment institutions, and empirically tests the influence of the role positioning of investment institutions on the value of start-up enterprises from the perspective of network. The research results show that the network centrality (relative centrality, closeness centrality) and the structural hole constraint of the joint venture capital network, as well as the leading and following investment position of investment institutions have a significant impact on the value of start-up enterprises. Additionally, the more central in the joint venture capital network the investment institutions are, the higher value of the start-up enterprises supported by them have; the more structural holes the investment institutions occupy, the higher value of the start-up enterprises supported by them have; the more prominent the leading position of the investment institutions is, the higher value of the start-up enterprises supported by them have. While, there is a negative relationship between the following investment position of investment institutions and the value of start-up enterprises supported by them.
\end{abstract}

Keywords: joint venture capital network; network centrality; leading status; following status; start-up enterprise value

\section{Introduction}

Socialism with Chinese characteristics has entered a new era. China's economy has shifted from high-speed growth to high-quality development. Venture capital plays an important role in deepening the financial supply-side structural reform and building a comprehensive and multi-level financial support service system. In the historical background of rapid technological change, all walks of life are developing in a "cross-border" manner, and the enterprise development requires the organic integration of resources and technologies of different industries. Although investment institutions can provide resources for start-up enterprises, the advantages of a single investment institution will obviously be weaker than the "alliance" of multiple investment institutions. Under this circumstance, investment institutions tend to provide funds and resources for the sustainable development of start-up enterprises through the joint venture capital network in the form of joint investment, so as to optimize resource allocation, reduce investment risks, and improve capital utilization efficiency [1].

A joint venture capital network refers to a partnership between two or more investment institutions that invest in the same start-up enterprise to form a network that can share risks, have mutual trust, and be mutually beneficial, and share the investment income. In the process of forming a joint venture 
capital network, there is usually a venture capital institution as the main investment institution [2], which is the leading investment institution of the venture capital network. Additionally, the leading investment institution invites other venture capital institutions to participate in the joint investment to form a joint venture capital network [3]. In addition, it has the largest share among the members participating in the joint venture capital network [4], so other investment institutions are the following investment institutions. The selection of a venture capital institution for a partner is a two-way choice. It should not only consider whether the project investment can meet its own development needs, but also consider whether the shareable information and resources can bring about an increase in its own value [5].

The joint venture capital network can break through the resource restriction of individual investment, and the investment institutions also can establish complementary advantages through sharing resources, so as to promote the value increment of start-up enterprises [6]. Through the joint investment behavior and long-term cooperation, the investment institutions have continuously expanded the scale of the joint venture investment network [7]. Research results at home and abroad show that joint investment can generate a synergistic effect from the aspects of fund raising [8], knowledge sharing [9], partner selection [10], network relationship construction [11,12], cooperation innovation [13], and so on, so as to promote the sustainable development of the start-up enterprise. Compared with individual investment, joint investment gives more support to start-up enterprises in terms of risk control, resource integration, and value-added service, so it plays an essential role in the value creation and sustainable development of start-up enterprises [1,7]. Start-up enterprises with a joint investment background not only have a stronger viability in the fierce competition, but also have a continuous motive power of development [14].

Venture capital not only plays an important role in supporting the sustainable development of start-up enterprises, but also plays an important role in promoting the transformation and upgrading of China's economic structure. However, in the actual development, there are still some problems to be resolved in partner selection, cooperation mode, and behavior relationship of the joint venture capital network. The low trust level and poor communication between cooperative partners make it difficult to continue the cooperation. In the operation process of venture capital, unhealthy phenomena such as adverse selection and free riding are caused due to information asymmetry and benefit distribution. Additionally, this will have a negative impact on the development of start-up enterprises. Therefore, from the perspective of network, the research on the impact of the role positioning of venture capital institutions and the value of start-up enterprises can help to regulate investment behavior, and it has an important significance in theory and practice for guiding investment institutions to support the growth and sustainable development of start-up enterprises and promoting the development of innovative economy. Based on this, the main contributions of this paper focus on the following three aspects: (1) from the perspective of network, based on the social network theory, this paper constructs a joint venture capital network, quantifies the network attributes of investment institutions, and explores the impact of network position of investment institutions on the value of start-up enterprises. (2) This paper introduces the Bonacich power index, measures the leading and following investment position of investment institutions in the network, and explores the impact of the role positioning of the investment institutions in the network on the value of the start-up enterprises. (3) Based on the relevant data of joint venture capital, this paper constructs a multivariate regression model, empirically tests the impact of the role positioning of investment institutions on the value of start-up enterprises, so as to provide theoretical support and reference for the sustainable development of venture capital institutions and start-up enterprises in China.

\section{Theoretical Analysis and Hypothesis}

The joint venture capital network will improve the resource sharing and value-added service quality of the venture capital institutions. The network provides a sharing platform for enterprises to acquire learning resources. Through joint investment, venture capital institutions can realize the 
exchange and cooperation in various aspects such as knowledge accumulation, technological advances, and investment experiences, so as to provide resources and value-added service for the sustainable development of start-up enterprises [15]. A joint venture capital network can alleviate the restriction of space and industry and provide a way for start-up enterprises to access innovative resources. The trust between the members of the joint venture capital network and the good reputation of investment institutions will provide such important resources as supervision and value-added service required for the listing of the company, enhance the core competitiveness and enterprise value of start-up enterprises, and promote the sustainable development of start-up enterprises [16].

Social network theory provides a new theoretical perspective for studying the interaction between individuals, between organizations, and organizational performance in social network. In social network theory, network relationship refers to the network connection relationship which is formed through communication and interaction of the direct or indirect connections established between the network members and other members due to their subjective needs or objective restrictions. Network connection is the basic unit in the study of social network relationship [17]. According to social network theory, the network characteristics of network member will affect the activities and results of itself and other nodes. The more favorable the position of investment institution is, the more resources and information it will obtain. Thus, it can control the content, direction, and frequency of resources and information to a certain extent in network transmission, while enterprises in other positions can only obtain indirect information [18].

Network members are usually only connected directly with trusted members, while they have no direct connection with other members. As a result, the network relationship appears to be broken, which is similar to the presence of holes in the network, called structural holes [19]. The position of structural holes has information and control advantages. Network members occupying the position of structural holes can obtain heterogeneous information and resources, which brings them a competitive advantage. As the only way to transmit information and resources, the position of structural holes also controls the path of information transmission and resource allocation, having a relative control advantage. The more structural hole positions the network member occupies, the more significant its position advantage will be, and the stronger influence and control in network it will have. Social network theory focuses on the number of structural holes occupied by network members, and it can reflect the strength of the relationship between network members [20].

According to previous studies, the network connection of venture capital institutions is measured in this paper by using the network position of social network research framework. In social network research, by using graph theory as a tool, the network position of network members is measured by calculating network centrality and structural hole limitations and its relative importance in network is also reflected [21].

\subsection{The Impact of Network Position of Investment Institutions on Start-Up Enterprises}

A favorable network position can promote venture capital institutions to achieve resource integration and information sharing, and better promote the value creation of start-up enterprises. Network position is one of the important features of network attributes. The centrality and structural holes describe the influence and control of venture capital institutions within the network. The investment institutions with high network centrality have higher reputation and popularity, and they can control the transmission of information and resources in the network. The network connection between the network members provides conditions for start-up enterprises to obtain accurate and effective information [22]. The position of structural holes helps venture capital institutions to obtain heterogeneous information and resources, and to acquire and control more communication channels of knowledge and information [23], which helps start-up enterprises to carry out innovative activities and enhance enterprise value.

In the network structure, the closer to the network center an investment institution supporting a start-up enterprise is, the more information and resources it will obtain, and the stronger ability 
to control information and resources it will have. Thus, it can effectively improve the accuracy of investment decisions and can establish a good reputation, which will help to strengthen the recognition and trust of other investment institutions and expands their influence in the joint venture capital network [24]. The stronger influence an investment institution in the network has, the closer to the network center its position is. The continuous success and development of an investment institution can form a cumulative advantage, which is the Matthew Effect. Therefore, under the Matthew Effect, the more information and resources a venture capital institution obtains, the closer to the network center its position is, and the more information and resources it will have, as well as the more significant support for start-up enterprises it will have. As a result, the value of start-up enterprises will be improved.

Based on the above theoretical analysis, the following hypothesis is proposed:

Hypothesis 1 (H1). There is a positive correlation between the network position of investment institutions and the value of start-up enterprises in the joint venture capital network.

For the measurement of the network position of joint venture capital, the relative importance of the members in the network is measured by calculating the network centrality and structural holes, which is the network position. In a venture capital network, the closer to the network center the network position of investment institution is, the more significant impact on investment efficiency it will have, and the more obvious promotion of information and resource advantages established through network connection on start-up enterprises it will produce [12]. The control power of network members in the network is measured and their utilization efficiency of network resources is reflected through structural holes. The investment institution which occupies more structural holes can help its supporting start-up enterprises to obtain more resources and information [25]. The venture capital institution which is in structural holes controls the path of information transmission and resource allocation and plays a significant role in promoting knowledge transfer and cooperative innovation [26]. There are many centrality indicators, and the joint venture capital network structure can be described in terms of influence, control ability, and communication ability. Therefore, the relative centrality, closeness centrality, and structural hole constraint are selected as the indicators to measure the network position of investment institutions. The higher relative centrality and closeness centrality an investment institution has, the stronger influence and control it will have in the network, and the more development of start-up enterprises it can promote. The less restrictive the structural holes of the investment institution are, the more structural holes it will occupy, the stronger ability to communicate in the network it will have, as well as the more positive impact on start-up enterprises it will have. Therefore, based on H1, three sub-hypotheses are proposed:

Hypothesis 1a (H1a). The relative centrality of investment institutions has a positive impact on the value of start-up enterprises.

Hypothesis $\mathbf{1 b} \mathbf{( H 1 b )}$. The closeness centrality of investment institutions has a positive impact on the value of start-up enterprises.

Hypothesis 1c (H1c). The structural hole constraint of investment institutions has a negative impact on the value of start-up enterprises.

\subsection{The Influence of the Role Positioning in Network of Investment Institutions on the Value of Start-Up Enterprises}

Joint investment can form a joint venture capital network, a platform for sharing resources and experience. On the basis of improving the ability of investment institutions to acquire resources, 
it breaks the geographical and industry restrictions of investment institutions, so as to provide high-quality value-added service for start-up enterprises, and enhance the value of start-up enterprises.

2.2.1. The Influence of Leading Investment Position of Investment Institutions on the Value of Start-Up Enterprises

In the joint venture capital network, the investment institutions with the leading investment position have rich information and resources, and the accuracy of their investment decisions and the success rate of their investment are higher. Therefore, they can gain recognition and trust from other investment institutions with the help of good reputation, expand their influence, and break the geographical and industry restrictions of investment institutions, so as to provide high-quality value-added service for start-up enterprises [27]. Leading investment institutions with high network position can not only choose high-quality start-up enterprises as investment targets, but also provide high-quality value-added services for them, thus, to increase the possibility, survival, and success rate of start-up enterprises in obtaining the next round of financing [28]. The start-up enterprises invested by leading investment institutions with high network position can obtain subsequent investment faster, and they are more likely to establish strategic alliances with well-known companies [29]. The leading investment institutions have the right to choose investment. They can make different investment strategies through partner selection and information asymmetry. Additionally, with the help of their influence and control in network, through sharing information and resources they can also grasp the important information of start-up enterprises and effectively solve the problem of information asymmetry, so as to effectively supervise all aspects of the operation and management of start-up enterprises and enhance enterprise value. Therefore, venture capital institutions with leading investment positions in the joint venture capital network can better help start-up enterprises to grow and enhance their enterprise value.

2.2.2. The Influence of Following Investment Position of Investment Institutions on the Value of Start-Up Enterprises

Venture capital institutions that are in the following investment position in the joint venture capital network often rely on the sharing resources and information of leading investment institutions to reduce the cost of information acquisition and project screening, so as to avoid investment risks. However, they also lose the initiative of investment choice. At the same time, the lack and lag of information transmission will lead to an increase in information asymmetry and investment uncertainty. As a result, the effectiveness of investment decisions will be reduced. When making investment decisions, investment institutions tend to be convergent, which is "Herd Behavior". Lux pointed out that "Herd Behavior" is a decision-making behavior in which the subject is influenced by the action of others, ignores his or her own private information, and imitates others while the information is incomplete [30]. In the joint venture capital network, the following investment institution will be affected by the Herd Effect when making investment decisions, which may lead to the failure of investment decisions. The following investment institutions may lack a full understanding of the comprehensive condition of start-up enterprises, so their support and assistance to the start-up enterprise is limited, which may not have a significant effect on the value promotion of start-up enterprises.

Based on the above analysis, the following hypotheses are proposed:

Hypothesis 2 (H2). The leading investment position of investment institutions has a positive impact on the value of start-up enterprises.

Hypothesis 3 (H3). The following investment position of investment institutions has a negative impact on the value of start-up enterprises.

The theoretical assumptions are shown in Figure 1. 


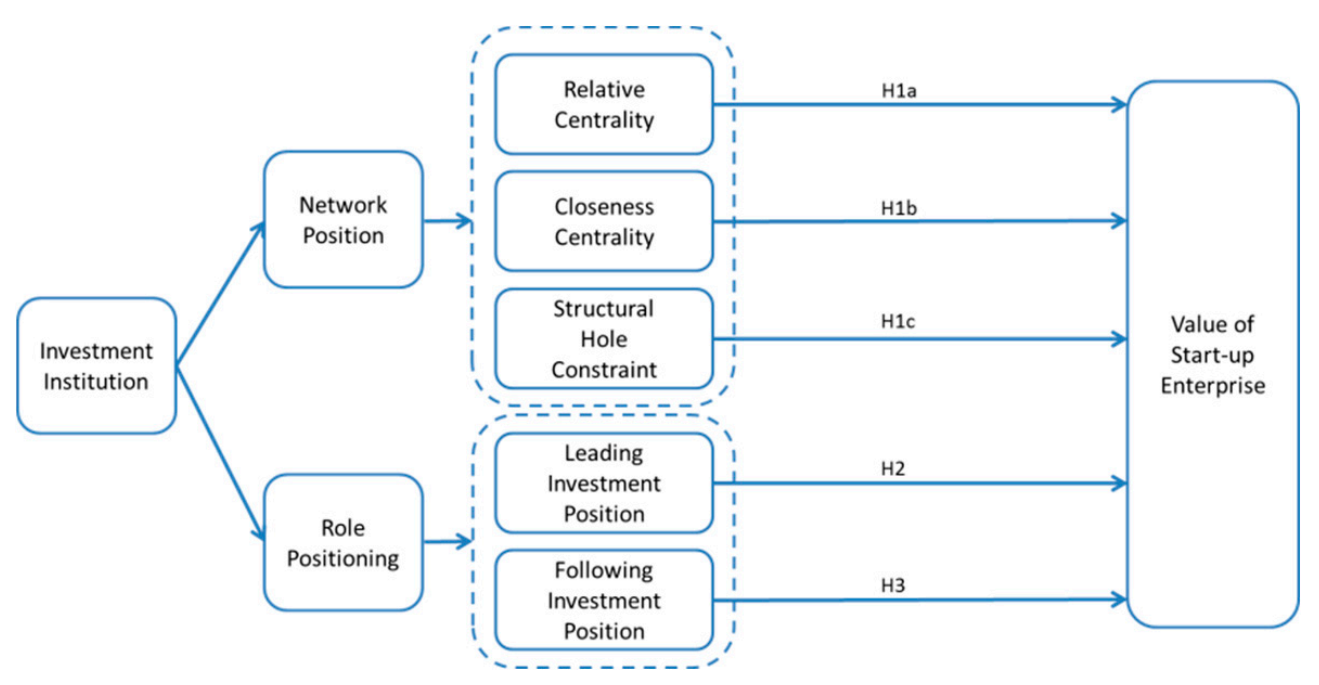

Figure 1. Theoretical assumption.

\section{Materials and Methods}

\subsection{Data Source}

The data came from the Wind China PE/VC Database. We selected start-up enterprises listed on the main board of Shanghai Stock Exchange, Shenzhen SME Board, and GEM from 1 January 2013 to 31 December 2017, excluding the samples without complete industries, information, and data, and screened out the start-up enterprises with detailed and accurate financial data, including the equity structure, operating conditions, income, and liabilities of the start-up enterprises, which can effectively reflect the enterprise value of the start-up enterprises. Finally, a total of 354 joint investment events of venture capital institutions on 174 start-up enterprises were collected. At the same time, the sole investment events of 98 venture capital institutions in 135 start-up enterprises were collected in order to compare with the innovative performance of venture capital supported by joint ventures.

\subsection{Variable Definition}

\subsubsection{Explained Variables}

Enterprise value is the sum of the existing profitability and future development potential of the resources and capabilities that the enterprise has. Enterprise value is the final product of value creation activities, and it is the unity of enterprise value source, value creation, and value realization. Enterprise value can be measured by Tobin's $Q$ value. Tobin's $Q$ value can effectively reflect the result of enterprise value creation, and it is a comprehensive reflection of the current value of tangible assets and intangible assets and the future value of start-up enterprises [31]. Based on financial data and market data, Tobin's $Q$ value can overcome the limitations of single data. Tobin's $Q$ value relies on the data with passive disclosure, authenticity, and timeliness, so it can objectively and accurately evaluate start-up enterprises. Therefore, this paper uses Tobin's $Q$ value to measure the value of start-up enterprises, (Tobin's Q expressed by TQ). Tobin's Q is the ratio of the market value to the book value of start-up enterprises. Additionally, the market value is expressed by the sum of the value of tradable shares, the value of non-tradable shares, and the book value of liabilities, while the book value is expressed by the book value of the total assets at the end of the period.

\subsubsection{Explanatory Variables}

(1) The network position centrality and structural hole

The network position centrality and structural hole are the characteristics of the "relationship" in the joint venture capital network. This paper describes the network position of the joint venture 
investment from two aspects of influence and control ability, and chooses relative centrality, closeness centrality, and structural hole constraint as indicators to measure the network position of investment institutions, which are, respectively, expressed by Degree, Closeness, and Constraint.

Relative centrality refers to the connection degree of an investment institution in the network to all the other investment institutions. It is the ratio of the direct connection number of the investment institution and other investment institutions in the network to its possible maximum connection number. The calculation formula is:

$$
\text { Degree }=\frac{d\left(n_{i}\right)}{m-1}
$$

In the formula, $d\left(n_{i}\right)$ stands for the connection number of each investment institution.

Closeness centrality is to measure the shortest path of each investment institution to other members in the network, which shows the effectiveness of information transmission. The calculation formula is:

$$
\text { Closeness }=\sum_{j=1}^{n} d_{i j} .
$$

In the formula, $n$ stands for the number of all nodes in the network and $d_{i j}$ stands for the shortcut distance between $i$ and $j$ (that is the line numbers in the shortcut). A high closeness centrality indicates that the investment institution has a greater influence in the aspects of information resource, rights, and reputation and this investment institution is located in the center of joint venture capital network.

Structural hole constraint is to measure the constraint degree of investment institutions by structural holes. In addition, the formula of investment institution $i$ constrained by $j$ is as follows:

$$
\text { Constraint }=\left(p_{i j}+\sum_{q} p_{i q} m_{q i}\right)^{2}
$$

In the formula, $p_{i q}$ is the proportion of input $q$ in the total relationship of investment institution $i$.

(2) The role positioning

The role positioning is to define the role of venture capital institutions based on the Bonacich Power Index, which can be divided into leading and following investment positions. The leading and following investment positions of venture capital institutions are determined by their centrality in the joint venture capital network, which are, respectively, represented as $P_{i t}$ and $C_{i t}$.

According to Bonacich's research, in the network, the centrality of nodes connected to the nodes with high centrality will be improved, and the centrality of other nodes connected with them will also be improved. Due to the relationship between centralities of nodes, this internal relationship circulation exists in the network. Therefore, Bonacich gives the formula to calculate the centrality with power index:

$$
\begin{gathered}
P_{i t}=\sum_{j} r_{i j}\left(\alpha+\beta P_{j t}\right) R_{i j t}, \\
C_{i t}=\alpha \sum R_{i j t}^{T} P_{j t}^{v} .
\end{gathered}
$$

$\alpha$ and $\beta$ are the corrected parameters. According to the formula, it can be seen that the power index takes into account the number of leading and following investments, which will better reflect the continuity and influence of investment institution position. The power index or influence of an investment institution can be used to evaluate the position and role of the investment institution in the field of venture capital.

\subsubsection{Control Variables}

Based on the previous research results and overcoming the influence of other factors on the value of venture enterprises, this paper introduces the establishment period, geographical position, 
ownership concentration, net profit rate, return on equity, and the investment industry diversity of investment institutions as control variables.

(1) The establishment period of a start-up enterprise

The establishment period of a start-up enterprise can be measured by "age" to indicate the position and state of the start-up enterprise in its development life cycle. The establishment period of a start-up enterprise is characterized by the time span from its establishment to the observation period of 31 December 2017. In general, the longer the start-up enterprise is established, the larger its scale is, the stronger its innovation capability is, and the higher its enterprise value is. It is expressed by the variable of Year.

(2) The geographical position of start-up enterprises

The geographical position of local start-up enterprises is mainly based on the position of its headquarters. The geographical position of foreign or joint venture is based on the position of its branch office in China. It is expressed by the variable of Position. It is set as 0 in the Beijing-Tianjin area, 1 in the Yangtze River Delta region, 2 in the Pearl River Delta region, and 3 in other regions.

\section{(3) Ownership concentration}

The ownership concentration can reflect the ownership structure of start-up enterprises and be measured by the shareholding ratio of top 10 shareholders, which is expressed by TOP 10 .

(4) Net profit rate

Net profit ate refers to the percentage of operating net profit to the invested capital, which can reflect the operating efficiency of start-up enterprises and is expressed by NPR.

(5) Return on equity

In the development process of enterprises, return on equity can indicate the income level of start-up enterprises. The higher the return on equity is, the stronger the vitality of the enterprise is and the stronger its growth ability is. The return on equity is controlled in this paper and it is expressed by ROE.

(6) The investment industry diversity of investment institutions

This paper selects the secondary industry classification standard of Wind Database. There are 24 secondary industries totally. The Herfindahl-Hirschman Index is adopted as an indicator of industry diversity, which is expressed by HHI. The formula is as follows:

$$
H H I=\sum_{j=1}^{24} \pi_{i j t}^{2} .
$$

In the formula, $\pi_{i j t}$ stands for the proportion of venture capital institution $i$ in the investment industry $j$ in the year of $t$.

The Herfindahl-Hirschman Index has a value range of $(0,1]$. This index can describe the agglomeration degree of venture capital investment industry in a certain region. The small index indicates a higher dispersion of venture capital in this region, a lower agglomeration degree of the industry, and a fiercer competition of investment institutions, while the large index indicates a higher concentration of venture capital in the region in a few industries, a higher agglomeration degree of the industry, and a higher degree of monopoly of investment institutions.

(7) Return on equity

In the development process of enterprises, return on equity can indicate the income level of start-up enterprises. The higher the return on equity is, the stronger the vitality of the enterprise is and 
the stronger its growth ability is. The return on equity is controlled in this paper and it is expressed by $R O E$.

The variable descriptions are shown in Table 1.

Table 1. Variable description table.

\begin{tabular}{|c|c|c|c|}
\hline Variable Type & Variable Name & Variable Code & Operational Definition \\
\hline Explained Variable & Tobin's Q Value & TQ & $\begin{array}{l}\text { Tobins's } \mathrm{Q}= \\
\text { the value of tradble shares }+ \text { the value of non-tradable shares }+ \text { the book value of liabilities } \\
\text { the book value of the total assets at the end of period }\end{array}$ \\
\hline \multirow{5}{*}{ Explanatory Variable } & Relative Centrality & Degree & The controllable range of investment institutions \\
\hline & Closeness Centrality & Closeness & $\begin{array}{l}\text { To measure the independence of each investment institution in the } \\
\text { network and the effectiveness of information transmission }\end{array}$ \\
\hline & Structural Hole Constraint & Constraint & Constraint $=\left(p_{i j}+\sum_{q} p_{i q} m_{q i}\right)^{2}$ \\
\hline & Leading Investment Position & $P_{i t}$ & $P_{i t}=\sum_{j} r_{i j}\left(\alpha+\beta P_{j t}\right) R_{i j t}$ \\
\hline & Following Investment Position & $C_{i t}$ & $C_{i t}=\alpha \sum R_{i j t}^{T} P_{j t}^{v}$ \\
\hline \multirow{4}{*}{ Control Variable } & $\begin{array}{l}\text { Establishment Period of } \\
\text { Start-Up Enterprises }\end{array}$ & Year & $\begin{array}{l}\text { The time span from the establishment to the observation period of } \\
\text { 31 December } 2017\end{array}$ \\
\hline & $\begin{array}{l}\text { Geographical Position of } \\
\text { Start-Up Enterprises }\end{array}$ & Position & $\begin{array}{l}\text { It is set as } 0 \text { if the head office of venture capital is in the Beijing city, } \\
1 \text { in the Yangtze River Delta region, } 2 \text { in the Pearl River Delta region, } \\
\text { and } 3 \text { in other regions. }\end{array}$ \\
\hline & $\begin{array}{l}\text { Industry Diversity of } \\
\text { Investment Institutions }\end{array}$ & HHI & $\begin{array}{c}H H I=\sum_{j=1}^{24} \pi_{i j t}^{2}\left(\pi_{i j t} \text { is the proportion of venture capital institution } i\right. \\
\text { in the investment industry } j \text { in the year of } t \text {.) }\end{array}$ \\
\hline & Return on Equity & $R O E$ & The ratio of net profit to owner's equity in a certain period \\
\hline
\end{tabular}

\subsection{Model Building}

A multiple regression model is built to test the hypotheses proposed in the previous section. The regression model is built as following.

$$
\begin{gathered}
T Q=\alpha_{0}+\alpha_{1} \text { Degree }+\alpha_{2} \text { Year }+\alpha_{3} \text { Position }+\alpha_{4} T O P 10+\alpha_{5} N P R+\alpha_{6} R O E+\alpha_{7} H H I \\
T Q=\beta_{0}+\beta_{1} \text { Closeness }+\beta_{2} \text { Year }+\beta_{3} \text { Position }+\beta_{4} T O P 10+\beta_{5} N P R+\beta_{6} R O E+\beta_{7} H H I \\
T Q=\chi_{0}+\chi_{1} \text { Constraint }+\chi_{2} \text { Year }+\chi_{3} \text { Position }+\chi_{4} T O P 10+\chi_{5} N P R+\chi_{6} R O E+\chi_{7} H H I \\
T Q=\delta_{0}+\delta_{1} P_{i t}+\delta_{2} \text { Year }+\delta_{3} \text { Position }+\delta_{4} T O P 10+\delta_{5} N P R+\delta_{6} R O E+\delta_{7} H H I \\
T Q=\gamma_{0}+\gamma_{1} C_{i t}+\gamma_{2} \text { Year }+\gamma_{3} \text { Position }+\gamma_{4} T O P 10+\gamma_{5} N P R+\gamma_{6} R O E+\gamma_{7} H H I .
\end{gathered}
$$

\section{Variable Index Calculations}

\subsection{Network Attribute Calculation}

In order to analyze the attributes of the joint venture capital network, the software UCINET 6.0 (University of California, Irvine, CA, USA) was used to describe the joint venture capital events and to construct the joint venture capital network of 2013-2017 studied in this section. The joint venture capital network structure is shown in Figure 2. 


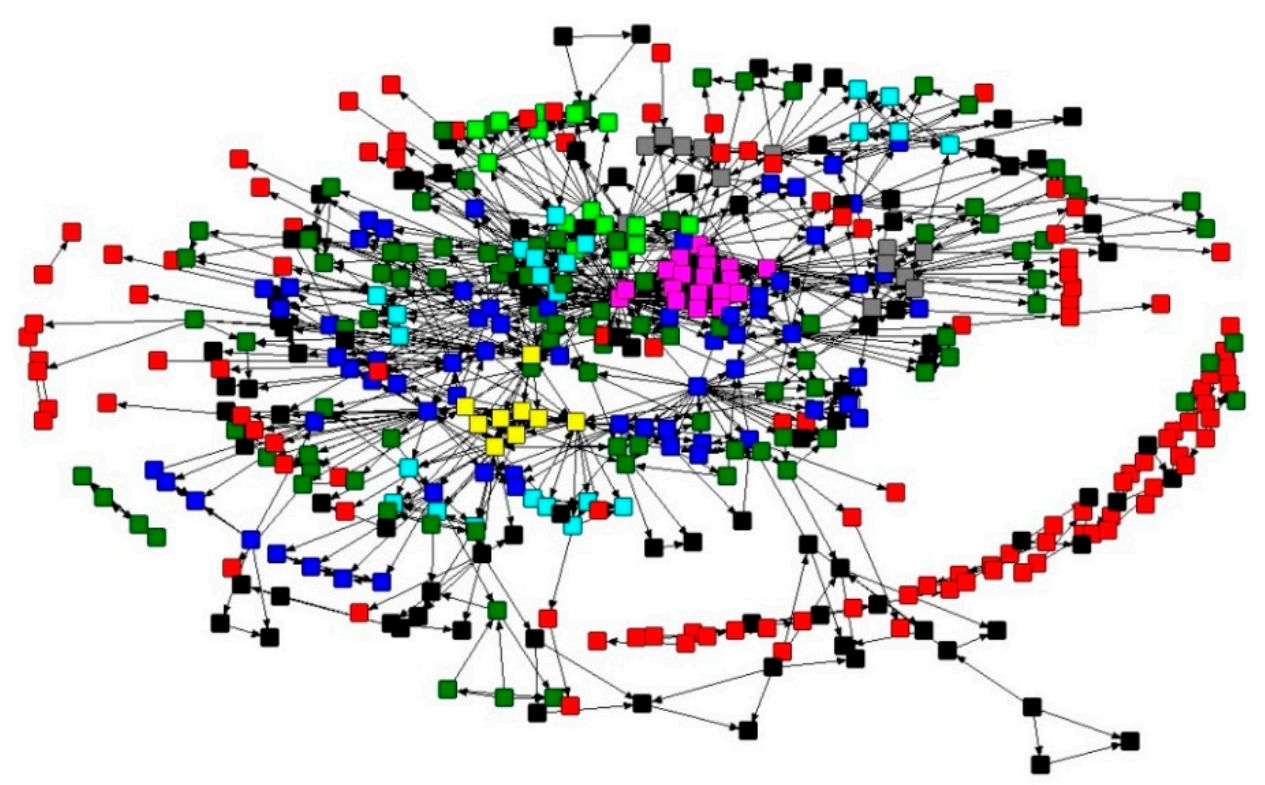

Figure 2. Syndication investment network structure of 2013-2017.

This section calculates the attribute index of joint venture capital network. Due to space limitation, it only lists the investment institutions with top five relative centralities and top five closeness centralities in the joint venture capital network. The calculation results are shown in Tables 2 and 3.

Table 2. The degree of joint venture capital network's member.

\begin{tabular}{cc}
\hline Investment Institution & Relative Centrality \\
\hline Goldstone Investment & 4.933 \\
Shenzhen Capital Group & 4.036 \\
Hengjin Investment & 3.587 \\
Shanghai Jiye Investment & 3.587 \\
Win-win Growth Investment & 3.139 \\
\hline
\end{tabular}

Table 3. The closeness of joint venture capital network's member.

\begin{tabular}{cc}
\hline Investment Institution & Closeness Centrality \\
\hline Dongsheng Venture Capital & 0.529 \\
Shanghai Jiye Investment & 0.526 \\
Hengjin Investment & 0.523 \\
Goldstone Investment & 0.518 \\
Lvy Capital & 0.515 \\
\hline
\end{tabular}

Structural hole constraint is to measure the ability of network members to use structural holes in the network. The lower the structural hole constraint is, the more the structural holes occupied by the network members are, and the better they can use the structural holes to expand the network scale and improve the network revenue. Due to space limitation, only investment institutions with the top five constraints in the joint venture capital network are listed. The calculation results are shown in Table 4. 
Table 4. The constraint structural holes of joint venture capital network's member.

\begin{tabular}{cc}
\hline Investment Institution & Structural Hole Constraint \\
\hline Shanghai Jiye Investment & 0.203 \\
International Development & 0.25 \\
Venture Capital & 0.273 \\
Goldstone Investment & 0.274 \\
Shenzhen Capital Group & 0.3 \\
Fortune Capital & \\
\hline
\end{tabular}

According to the calculation results of structural hole constraint, the results of the structural hole constraint of members in the joint venture capital network are in the range of $[0.203,1.125]$. Investment institutions that occupy more structural holes can contact the unconnected investment institutions, so as to obtain more heterogeneous information and resources, give a full play to the advantages of joint venture capital networks, and gain recognition and respect from other investment institutions and establish a good cooperation relationship.

\subsection{Network Position Calculation}

For the joint venture capital network, the relationship of network members is the main content of the network, and the centrality in the research method of social network is adopted to describe the centrality of the network members. In the joint venture capital network, the higher centrality of an investment institution indicates a more central position in the network, a closer relationship with other members of the network, and also a greater impact.

It can be seen from Equations (4) and (5) that $P_{i t}$ represents the leading investment position of investment institution $i$ in the year of $t$ and $C_{i t}$ represents the following investment position of investment institution $i$ in the year of $t . r_{i j}$ represents the investment number of the venture capital institution $i$ with a leading position and the investment institution $j$ with a following position. Additionally, $R_{i j t}$ is a matrix of $r_{i j}$ in the year of $t$. The scale factor $\alpha$ was chosen in this paper to ensure that $P_{i t}$ is kept in a relatively stable range in different network scales. The parameter $\beta$ indicates the impact of the leading position of investment institutions in the joint venture capital network by the leading position of other investment institutions. If $\beta=0$, the leading position of venture capital institutions is completely linearly related to the number of investments in the year.

Figure 3 is about the leading position and following position of investment institutions in the joint venture capital network. The larger the value of $P_{i t}$ is, the more obvious the leading position of investment institutions is; the larger the value of $C_{i t}$ is, the more obvious the following position of investment institutions is. The line in the figure is $C_{i t}=0.7811 P_{i t}+0.6088$. Additionally, for the part below the line, it shows $C_{i t}<0.7811 P_{i t}+0.6088$, which means the obvious leading position of investment institutions. From the establishment of the start-up enterprises, these institutions have participated in the management of the start-up enterprises, and then other investment institutions also gradually participate.

As for the part above the line, it indicates $C_{i t}>0.7811 P_{i t}+0.6088$ and the following position of investment institutions is more significant. Usually these institutions join the investment in the later period. Under the influence of the leading investment institutions, they cooperate with the leading investment institutions depending on their professional capabilities or financing channels, so as to jointly help start-up enterprises to grow and develop. According to Figure 3, it can be seen that there are fewer points on the line, which indicates that it is difficult for an investment institution to gain an obvious leading position and an obvious following position at the same time. That is to say, it is difficult to get a large $P_{i t}$ and a large $C_{i t}$ at the same time. 


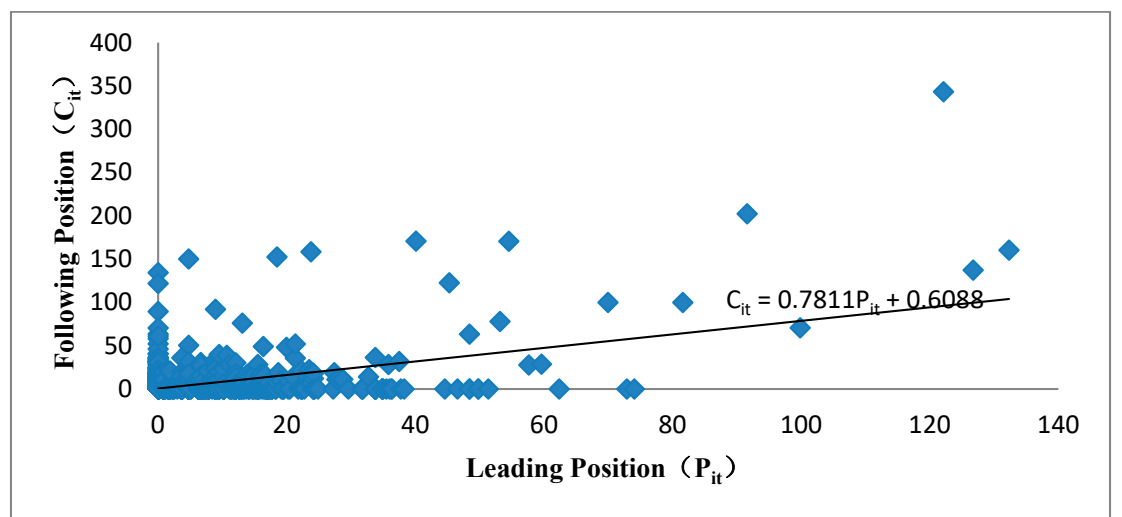

Figure 3. Venture capital institutions' leading and following positions.

\section{Results and Discussion}

In this paper, the software Eviews6.0 (IHS Global Inc., Irvine, CA, USA) was used to calculate the results of the constructed multiple regression models. The results of multiple regression models are shown in Table 5.

Table 5. The results of multiple regression analysis models.

\begin{tabular}{|c|c|c|c|c|c|}
\hline Variable & Model 7 & Model 8 & Model 9 & Model 10 & Model 11 \\
\hline Degree & $\begin{array}{c}0.195^{* * *} \\
(0.000)\end{array}$ & & & & \\
\hline Closeness & & $\begin{array}{c}5.018^{* * * *} \\
(0.001)\end{array}$ & & & \\
\hline Constraint & & & $\begin{array}{c}-0.800^{* * *} \\
(0.004)\end{array}$ & & \\
\hline$P_{i t}$ & & & & $\begin{array}{c}0.012^{* * *} \\
(0.000)\end{array}$ & \\
\hline$C_{i t}$ & & & & & $\begin{array}{l}-0.373 \\
(0.296)\end{array}$ \\
\hline Year & $\begin{array}{l}0.341^{* *} \\
(0.042)\end{array}$ & $\begin{array}{c}0.258 \\
(0.126)\end{array}$ & $\begin{array}{l}0.317 * \\
(0.064)\end{array}$ & $\begin{array}{l}0.312 * \\
(0.061)\end{array}$ & $\begin{array}{l}0.297 * \\
(0.075)\end{array}$ \\
\hline Position & $\begin{array}{l}-0.169 \\
(0.239)\end{array}$ & $\begin{array}{l}-0.145 \\
(0.320)\end{array}$ & $\begin{array}{l}-0.203 \\
(0.166)\end{array}$ & $\begin{array}{l}-0.146 \\
(0.307)\end{array}$ & $\begin{array}{l}-0.140 \\
(0.331)\end{array}$ \\
\hline TOP10 & $\begin{array}{l}-0.021 \\
(0.000)\end{array}$ & $\begin{array}{l}-0.021 \\
(0.000)\end{array}$ & $\begin{array}{l}-0.021 \\
(0.000)\end{array}$ & $\begin{array}{l}-0.021 \\
(0.000)\end{array}$ & $\begin{array}{l}-0.021 \\
(0.000)\end{array}$ \\
\hline$N P R$ & $\begin{array}{l}0.014 \text { * } \\
(0.056)\end{array}$ & $\begin{array}{l}0.013 * \\
(0.074)\end{array}$ & $\begin{array}{l}0.013 * \\
(0.067)\end{array}$ & $\begin{array}{l}0.013 * \\
(0.065)\end{array}$ & $\begin{array}{l}0.013 * \\
(0.070)\end{array}$ \\
\hline$R O E$ & $\begin{array}{c}0.038^{* *} \\
(0.016)\end{array}$ & $\begin{array}{l}0.037^{* *} \\
(0.024)\end{array}$ & $\begin{array}{c}0.040^{* *} \\
(0.013)\end{array}$ & $\begin{array}{c}0.038^{* *} \\
(0.017)\end{array}$ & $\begin{array}{c}0.039 * * \\
(0.014)\end{array}$ \\
\hline HHI & $\begin{array}{l}-0.231 \\
(0.211) \\
\end{array}$ & $\begin{array}{c}-0.451 \text { ** } \\
(0.010)\end{array}$ & $\begin{array}{l}-0.054 \\
(0.829)\end{array}$ & $\begin{array}{l}-0.269 \\
(0.134)\end{array}$ & $\begin{array}{c}-0.363^{* *} \\
(0.037)\end{array}$ \\
\hline C & $\begin{array}{l}-0.168 \\
(0.911)\end{array}$ & $\begin{array}{c}-0.187 \\
(0.904)\end{array}$ & $\begin{array}{c}0.710 \\
(0.636)\end{array}$ & $\begin{array}{c}0.208 \\
(0.888)\end{array}$ & $\begin{array}{c}0.465 \\
(0.752)\end{array}$ \\
\hline $\mathrm{R}^{2}$ & 0.169 & 0.147 & 0.143 & 0.173 & 0.171 \\
\hline Adjustment- $\mathrm{R}^{2}$ & 0.154 & 0.131 & 0.128 & 0.158 & 0.156 \\
\hline F-statistic & 11.097 & 9.379 & 9.099 & 11.403 & 11.226 \\
\hline
\end{tabular}

Note: ${ }^{* * *}, * *$ and ${ }^{*}$ respectively present the significance at the statistical levels of $1 \%, 5 \%$ and $10 \%$. 


\subsection{The Impact of Network Position of Investment Institutions on the Start-Up Enterprise Value}

The result of Model 7 shows that there is a significant positive correlation between relative centrality and the value of start-up enterprises. Investment institutions with a higher centrality have a larger number of other members connected in the network and have better resources than other investment institutions. The information asymmetry brings about a sharp decline in cost. Therefore, investment institutions can hold more shares, strengthen the connection with the board of directors, and better participate in the management and supervision of start-up enterprises. At the same time, investment institutions can share information through the joint venture capital network, grasp more important information of enterprises, and effectively solve the problem of information asymmetry. Through effectively supervising all aspects of start-up enterprises, investment institutions also can enhance their management level, effectively increase their value, and promote their sustainable development. H1a is verified.

The result of Model 8 shows that there is a significant positive correlation between closeness centrality and enterprise value. Investment institutions with a high closeness centrality can enhance their influence and control and obtain more information and resources, based on information and resource sharing, talent exchange, and technical cooperation. What is more, they also can help start-up enterprises to attract some outstanding underwriters and effectively restrain a speculative psychology of other members in the network and possible moral hazard. As a result, their certification and supervision functions can be fully played, the Initial Public Offering underpricing level can be reduced, and the value of start-up enterprises can be enhanced. H1b is verified.

The result of Model 9 shows that there is a significant negative correlation between the structural hole constraint of investment institutions in the joint venture capital network and the value of start-up enterprises. That is to say, as the structural hole constraints of investment institutions are reduced, the value of start-up enterprises they support is raised. The results show that the more structural hole positions investment institutions occupy, the better they can control the acquired heterogeneous information and knowledge. Additionally, they can gain benefits from information asymmetry, so as to consolidate the advantages of the structural hole position, better provide value-added service for start-up enterprises, and transfer the acquired heterogeneous information and knowledge to start-up enterprises. Thus, they can help start-up enterprises accurately grasp market opportunities and enhance the value of start-up enterprises. Therefore, H1c is verified.

The study of Hochberg, Ozmel et al. shows that investment institutions with high network positions can provide more high-quality value-added services to start-up enterprises, and promote their growth, sustainable development, and increase of value [28,29]. The conclusion of this paper is consistent with that of Hochberg and Ozmel et al. In summary, the higher the relative centrality and closeness centrality of investment institutions in the joint venture capital network are, the lower the structural hole constraint is. That is to say, the better the network position of investment institutions in the joint venture capital network is, the higher the value of start-up enterprises supported by them is. $\mathrm{H} 1$ is verified.

\subsection{The Impact of Role Positioning of Investment Enterprises on the Start-Up Enterprise Value}

Model 10 measures the regression results of the impact of investment institutions' leading position in the joint venture capital network on the value of the start-up enterprises. The result shows that there is a significant positive correlation between the leading position of investment institutions and the value of start-up enterprises. The joint venture capital network can realize information and resource spread among investment institutions. The higher the leading position of investment institutions is, the more obvious their advantage of obtaining information and resources is, and the stronger their control ability of the information and resource transmission path in the joint venture capital network is. Thus, they can preferentially access useful information and scarce resources.

The study of Megginson and Weiss et al. shows that investment institutions with leading investment positions in joint investment play a strong certification and supervision role in start-up 
enterprises, sending a signal that the start-up enterprise is of high quality to the outside investors, obtaining and providing more resources to the start-up enterprise to promote its rapid development [32]. The conclusion of this paper is consistent with the that of Megginson and Weiss. Investment institutions with leading positions can bring more resources and value-added service to start-up enterprises, relying on their advantages of comprehensive information, enough resources, and good reputation. When investment institutions have a strong influence, the certification role of investment institutions will be strengthened. Thus, it will convey to the market the signal that start-up enterprises have good quality and strong competitiveness. As a result, it will increase the recognition of the external market to the market value of start-up enterprise and promote the value of start-up enterprises. $\mathrm{H} 2$ is proved.

According to the regression result of Model 11, it can be seen that there is a negative correlation between the following position of investment institutions and the value of start-up enterprises, but it is not obvious. If investment institutions with leading positions invite other investment institutions to participate in the joint investment, the reason is usually that it is difficult for leading investment institutions to confirm the development uncertainty of start-up enterprises, so as to avoid risks as much as possible. If there are other investment institutions willing to invest for the start-up enterprises, it means that the project has been confirmed by other investment institutions. If there is no other investment institution willing to invest, the feasibility of the project needs to be further confirmed. As investment institutions with following positions have a lag of information acquisition, resource allocation, project screening, etc., to a certain extent the Herd Effect weakens the influence of investment institutions with following positions on the start-up enterprises. However, information asymmetry further aggravates the Herd Effect. If they can obtain more comprehensive information timely, they will be in a more favorable position. In fact, investment institutions with following positions are at a disadvantage whether in the ability to obtain information or the channel to obtain information. Due to the information asymmetry, it will also increase the investment risk of investment institutions with following positions. At the same time, it will also cause the evaluation failure of start-up enterprises and the less master of core information of start-up enterprises. As a result, to a certain extent, investment institutions with following positions will have an adverse impact on the value of start-up enterprises. Therefore, $\mathrm{H} 3$ is verified.

\subsection{Endogenous Test and Robustness Test}

\section{(1) Endogenous test}

The test results of the multiple regression model showed the impact of the joint venture investment network on the technological innovation of start-up enterprises. As investment institutions have a preference for start-up enterprises with large-scale assets, strong profitability, and high levels of management, there may be errors of sample selection in the above regression analysis, which will lead to endogenous interference in the research results. In this paper, the propensity score matching method was used to further test the robustness of the results to eliminate endogeneity. With reference to the research methods of Yang Zhuqing and Liu Shaobo [33], this aim of this section is to find the control group for the processing group, match the propensity scores, and test the impact of the joint venture investment network on the technological innovation of the start-up enterprises.

Start-up enterprises were divided into treatment group (joint investment support) and control group (sole investment support) according to joint investment support and sole investment support. Full consideration was given to the influencing factors that affect the investment preferences of investment institutions. Additionally, the total assets, industry, return on assets, and return on investment were chosen as matching variables for propensity score matching.

Figure 4 shows probability density functions of two groups' propensity scores after the nearest neighbor matching method. It can be seen that before matching, the probability density distributions of the propensity scores between the control group and the treatment group are significantly different, which indicates that the characteristics of two groups of start-up enterprises vary greatly, and the investment preferences of investment institutions also will be affected by the characteristics of start-up 
enterprises. After matching, the propensity scores of the control group and the treatment group have a more consistent probability density distribution, indicating that the characteristics of the two groups of enterprises are similar, which reduces the impact of the investment preferences of investment institutions on the research results.
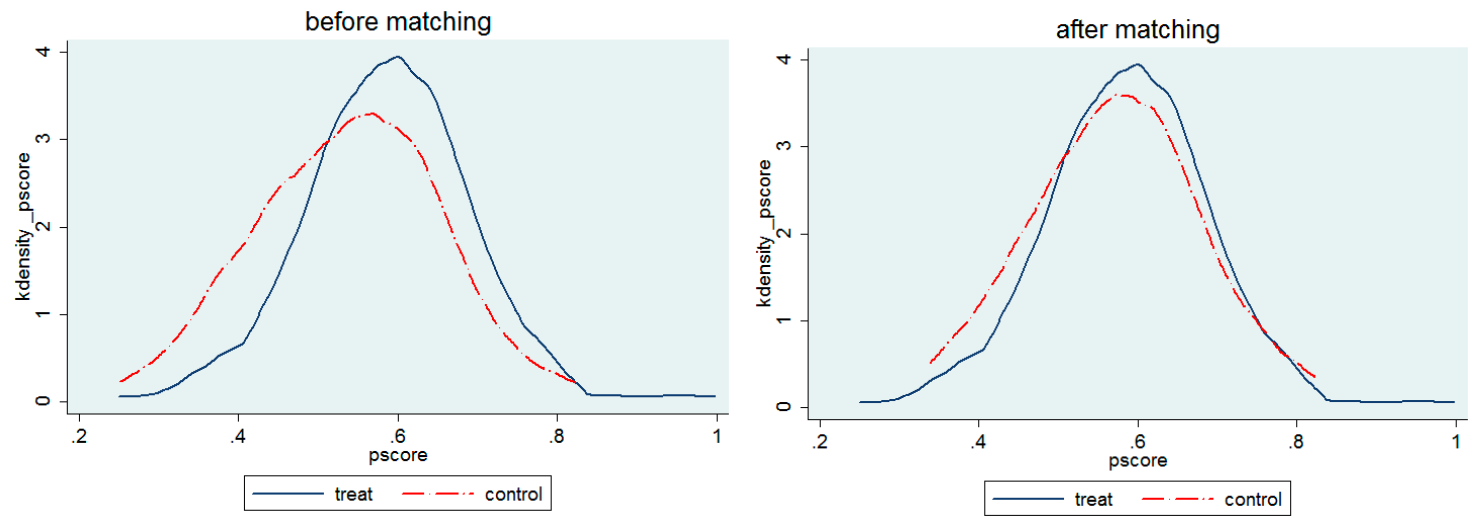

Figure 4. Propensity score probability density distribution before and after matching.

Table 6 lists the average treatment effect (ATT) of the start-up enterprise value Tobin's Q value of the treatment group and the control group using different matching methods. The ATT values obtained by nearest neighbor matching and radius matching are both positive, both of which are significant at the level of $1 \%$, indicating that the joint venture investment network has a significant impact on promoting the value of start-up enterprises. This is consistent with the test results in Table 5 of the multiple regression results, and the hypothesis is proved.

Table 6 . The results of average treatment effect test to eliminate endogeneity.

\begin{tabular}{cccccc}
\hline Variable & Matching Method & $\begin{array}{c}\text { Treatment } \\
\text { Group }\end{array}$ & Control Group & $\begin{array}{c}\text { Average Treatment } \\
\text { Effect (ATT) }\end{array}$ & T Value \\
\hline \multirow{2}{*}{ Tobin's Q } & $\begin{array}{c}\text { Nearest Neighbor } \\
\text { Matching }\end{array}$ & 168 & 123 & $0.543^{* * *}$ & 3.292 \\
& Radius Matching & 168 & 123 & $0.773^{* * *}$ & 3.951 \\
\hline
\end{tabular}

Note: the nearest neighbor matching and radius matching methods are implemented respectively through attnd and attr commands. The radius matching value is set as 0.001 , the number of repeated sampling is 500 , and the standard error is estimated by Bootstrap.

\section{(2) Robustness test}

The purpose of the robustness test is to check whether the empirical results keep appropriate robustness as the parameter settings change. If the symbol and significance of the empirical results are basically unchanged after changing the parameter settings, it indicates that the empirical results have appropriate robustness. On the contrary, it indicates that the model estimation does not have robustness. Therefore, in order to ensure the reliability of the research conclusion, the robustness test was performed through replacing the variables with re-regression.

Most of the variables involved in the research are proxy variables, which may have deviation. Therefore, for the variables of the joint venture investment network, "intermediate centrality" and "structural hole effectiveness" were used as substitute variables. For the value of start-up enterprises, "the average market value of the start-up enterprises of the first three years after listing" was used as a substitute variable. They were substituted into the original model, keeping other variables unchanged. The regression results of the model are shown in Table 7.

There is a significant positive correlation between intermediate centrality, closeness, structural hole efficiency, and the value of start-up enterprises and a significant positive correlation between the leading position of investment institutions and the value of start-up enterprises. However, there is a 
negative correlation between the following position of investment institutions and the value of start-up enterprises, but it is not significant. The test results are consistent with the results of the original model, which indicates that the model passed the robustness test.

Table 7. The results of multiple regression analysis model with substitute variables.

\begin{tabular}{|c|c|c|c|c|c|}
\hline Variable & Model 7' & Model 8' & Model 9' & Model 10' & Model 11' \\
\hline Intermediate & $\begin{array}{l}1.930 * * \\
(0.028)\end{array}$ & & & & \\
\hline Closeness & & $\begin{array}{c}13.171^{* *} \\
(0.011)\end{array}$ & & & \\
\hline Efficiency & & & $\begin{array}{c}0.345^{* * *} \\
(0.008)\end{array}$ & & \\
\hline$P_{i t}$ & & & & $\begin{array}{l}0.003 * \\
(0.088)\end{array}$ & \\
\hline$C_{i t}$ & & & & & $\begin{array}{l}-0.001 \\
(0.167)\end{array}$ \\
\hline Year & $\begin{array}{c}-0.486^{* * *} \\
(0.000)\end{array}$ & $\begin{array}{c}-0.460 * * * \\
(0.000)\end{array}$ & $\begin{array}{c}-0.464^{* * *} \\
(0.000)\end{array}$ & $\begin{array}{c}-0.476^{* * *} \\
(0.000)\end{array}$ & $\begin{array}{c}-0.479^{* * *} \\
(0.000)\end{array}$ \\
\hline Position & $\begin{array}{l}-0.173 \\
(0.113) \\
\end{array}$ & $\begin{array}{c}0.126 \\
(0.254) \\
\end{array}$ & $\begin{array}{c}0.130 \\
(0.238) \\
\end{array}$ & $\begin{array}{c}0.172 \\
(0.116) \\
\end{array}$ & $\begin{array}{c}0.173 \\
(0.116)\end{array}$ \\
\hline TOP10 & $\begin{array}{l}-0.060 \\
(0.492) \\
\end{array}$ & $\begin{array}{l}-0.070 \\
(0.424)\end{array}$ & $\begin{array}{l}-0.035 \\
(0.686) \\
\end{array}$ & $\begin{array}{l}-0.042 \\
(0.631) \\
\end{array}$ & $\begin{array}{l}-0.039 \\
(0.653)\end{array}$ \\
\hline$N P R$ & $\begin{array}{c}-0.346^{* * *} \\
(0.000)\end{array}$ & $\begin{array}{c}-0.316^{* * *} \\
(0.001)\end{array}$ & $\begin{array}{c}-0.310^{* * *} \\
(0.001)\end{array}$ & $\begin{array}{c}-0.349 * * * \\
(0.000)\end{array}$ & $\begin{array}{c}-0.347^{* * *} \\
(0.000)\end{array}$ \\
\hline$R O E$ & $\begin{array}{l}-0.002 \\
(0.634)\end{array}$ & $\begin{array}{c}0.001 \\
(0.650) \\
\end{array}$ & $\begin{array}{l}-0.002 \\
(0.576)\end{array}$ & $\begin{array}{c}0.002 \\
(0.386) \\
\end{array}$ & $\begin{array}{c}0.002 \\
(0.408)\end{array}$ \\
\hline HHI & $\begin{array}{c}0.002 \\
(0.408) \\
\end{array}$ & $\begin{array}{l}-0.002 \\
(0.602)\end{array}$ & $\begin{array}{c}0.003 \\
(0.333) \\
\end{array}$ & $\begin{array}{l}-0.002 \\
(0.631)\end{array}$ & $\begin{array}{l}-0.002 \\
(0.626)\end{array}$ \\
\hline $\mathrm{C}$ & $\begin{array}{c}16.943^{* * *} \\
(0.000)\end{array}$ & $\begin{array}{c}13.800 * * * \\
(0.000)\end{array}$ & $\begin{array}{c}16.950 * * * \\
(0.000)\end{array}$ & $\begin{array}{c}16.846^{* * *} \\
(0.000)\end{array}$ & $\begin{array}{c}16.890 * * * \\
(0.000)\end{array}$ \\
\hline $\mathrm{R}^{2}$ & 0.116 & 0.119 & 0.120 & 0.112 & 0.110 \\
\hline Adjustment- $\mathrm{R}^{2}$ & 0.100 & 0.103 & 0.104 & 0.096 & 0.094 \\
\hline F-statistic & 7.130 & 7.353 & 7.428 & 6.854 & 6.714 \\
\hline
\end{tabular}

\section{Conclusions and Implications}

The network centrality (relative centrality, closeness centrality) and the structural hole constraint of the joint venture capital network, as well as the leading and following investment position of investment institutions have a significant impact on the value of start-up enterprises. Additionally, the more central in the joint venture capital network the investment institutions are, the higher value of the start-up enterprises supported by them have; the more structural holes the investment institutions occupy, the higher value of the start-up enterprises supported by them have; the more prominent the leading position of the investment institutions is, the higher value of the start-up enterprises supported by them have. While, there is a negative relationship between the following investment position of investment institutions and the value of start-up enterprises supported by them.

The joint venture capital network can provide experience and resources for investment institutions. Additionally, investment institutions should use the experience to make up for their own shortcomings and use network resources to enhance their own strength. Leading investment institutions should 
accumulate and cultivate favorable network resources so as to achieve effective development, while following investment institutions should avoid blind investment and effectively identify investment projects so as to achieve effective development. Investment institutions with a leading position should make full use of their high investment performance to establish a reputation mechanism and a trust mechanism in the network, so as to increasingly enhance their influence and ensure their leading positions while obtaining investment income and enhancing their strength. In addition, investment institutions with a following position should get learning opportunities through the joint venture capital network, so as to enhance their comprehensive strength, expand the information channels, and master network resources as much as possible, thus gradually realizing their own growth. Avoiding and mitigating the Herd Effect can effectively promote the stable and healthy development of China's venture capital industry. Start-up enterprises should strengthen their cooperation with investment institutions in the joint venture capital network. The financial and intellectual capital acquired by the start-up enterprise from the network is the basis of the sustainable development of the enterprises. Additionally, the management experience and high-quality value-added service brought by the investment institutions are the guarantee of the sustainable development. Only by strengthening cooperation and exchanges with investment institutions and establishing stable cooperative relationships based on trust, start-up enterprises can better obtain the information and resources needed for their development, to timely and accurately grasp market dynamics to carry out technological innovation activities, and enhance innovation performance. As a result, they can establish their own core competitiveness and achieve stable and sustainable development for a long time.

The research results have a certain guiding significance for venture capital practice. Under the background of financial marketization reform, the powerful cooperation of strong investment institutions can promote information transmission and resource sharing, giving a full play to the resource agglomeration effect of the network and effectively improving the effectiveness of project selection. What is more, it can also provide high-quality value-added services and promote the value of start-up enterprises. At the same time, investment institutions need to further enhance their positions in the network, obtain more information and resources, improve the efficiency of investment decisions, and expand their influence. However, rational decisions should be made in the investment process. Additionally, the "Herd Effect" and the failure because of blindly following investment also should be avoided, so as to promote the stable development of the venture capital industry.

However, there are still some limitations in this study. First of all, this paper only considered the impact of the role positioning of investment institutions in the joint venture investment network on the value of start-up enterprises, but it did not undertake an in-depth study on factors which affect the network positions of investment institutions. Secondly, there are many factors affecting the value of a start-up enterprise, such as the level of technological innovation and the industry to which it belongs. Therefore, from a network perspective, the factors that affect the network position of investment institutions, the relationship between the network characteristics of investment institutions, and the innovation level of start-up enterprises and the differences between different industries still need to be further explored and studied.

Author Contributions: Conceptualization, T.L.; Data curation, T.L.; Formal analysis, T.L.; Methodology, S.Q.; Supervision, S.Q. and C.M.S.; Writing—original draft, T.L.; Writing—review and editing, S.Q. and C.M.S. All authors have read and agreed to the published version of the manuscript.

Funding: This research was funded by the Fundamental Research Funds for the Central Universities (Grant No. HIT. HSS. 201836).

Acknowledgments: The first author would like to thank dearly to Xiaofeng Hui for his theoretical guidance. In the same way, the authors thank to Chaoxuan Mao for his participation and technical support. This research has been supported by the Fundamental Research Funds for the Central Universities (Grant No. HIT. HSS. 201836).

Conflicts of Interest: The authors declare no conflict of interest. 


\section{References}

1. Wadhwa, A.; Phelps, C.; Kotha, S. Corporate Venture Capital Portfolios and Firm Innovation. J. Bus. Ventur. 2016, 31, 95-112. [CrossRef]

2. Wright, M.; Lockett, A. The Structure and Management of Alliances: Syndication in the Venture Capital Industry. J. Manag. Stud. 2003, 40, 2073-2102. [CrossRef]

3. Nitani, M.; Riding, A. Fund Size and the Syndication of Venture Capital Investments. Ventur. Cap. 2013, 15, 53-75. [CrossRef]

4. Meuleman, M.; Wright, M.; Manigart, S.; Lockett, A. Private Equity Syndication: Agency Costs, Reputation and Collaboration. J. Bus. Financ. Account. 2009, 36, 616-644. [CrossRef]

5. Dimov, D.; Milanov, H. The Interplay of Need and Opportunity in Venture Capital Investment Syndication. J. Bus. Ventur. 2010, 25, 331-348. [CrossRef]

6. Miller, N.H.; Weinberg, M.C. Understanding the Price Effects of the MillerCoors Joint Venture. Econom. 2017, 85, 1763-1791. [CrossRef]

7. Colombo, M.G.; Murtinu, S. Venture Capital Investments in Europe and Portfolio Firms' Economic Performance: Independent Versus Corporate Investors. J. Econ. Manag. Strategy. 2017, 26, 35-66. [CrossRef]

8. Feng, B.; Dang, X.; Yang, M. The Impact of Venture Capital Firms' Network Status on Their Cross-regional Fundraising. Forecast 2015, 34, 48-53.

9. Ji, Y.; Dang, X.; Gong, Z. Study on the Mechanism of Knowledge-sharing Behavior in the Technological Innovation Network-Based on the Perspective of Knowledge Power Asymmetry. Forecast 2014, 33, 8-14.

10. Wang, Y.; Dang, X.; Wang, X.; Luo, J.; Shi, Y. Partner Selection in the Formation of Venture Capital Syndication: Resourceaccumulation or similarity matching? Sci. Res. Manag. 2015, 36, 144-151.

11. Wu, J.; Zhang, J.; Nie, F. The Impact of Network Embeddedness on Joint Venture Capitals' Information Superiority. Sci. Res. Manag. 2016, 37, 143-151.

12. Cai, N.; He, X. Can Social Networks Improve the Value-added Effect of VC? Based on the Relationship of Venture Capital Networks and Investment Efficiency. J. Financ. Res. 2015, 426, 178-193.

13. Ma, N.; Meng, W. The Synergistic Effect Test on Venture Capital and Intellectual Capital at the Perspective of Joint Venture Capital. Forecast 2017, 36, 30-36.

14. Lehmann, E.E. Does venture capital syndication spur employment growth and shareholder value? Evidence from German IPO data. Small Bus. Econ. 2006, 26, 455-464. [CrossRef]

15. Antarciuc, E.; Zhu, Q.; Almarri, J.; Zhao, S.; Feng, Y.; Agyemang, M. Sustainable venture capital investments: An enabler investigation. Sustainability 2018, 10, 1204. [CrossRef]

16. Gompers, P.; Kovner, A.; Lerner, J. Specialization and Success: Evidence from Venture Capital. J. Econ. Manag. Strategy 2009, 18, 817-844. [CrossRef]

17. Granovetter, M. The Strength of Weak Ties: A Network Theory Revisited. Sociol. Theory 1983, 1, $201-233$. [CrossRef]

18. Dang, X.; Dong, J.; Chen, R. Study on the lmpact of Venture Capital Firms'Network Positions on Their Exit Way. China Soft Sci. 2011, 6, 156-166.

19. Burt, R.S. Structural Holes: The Social Structure of Competition; Harvard University Press: Cambridge, UK, 1992.

20. Goyal, S.; Vega-Redondo, F. Structural holes in social networks. J. Econ. Theory 2007, 137, 460-492. [CrossRef]

21. Abell, P.; Nisar, T.M. Performance Effects of Venture Capital Firm Networks. Manag. Decis. 2007, 45, 923-936. [CrossRef]

22. Xue, C.; Dang, X.; Ren, Z. The Impact of Venture Capital Firms' Reputation on Their Decision Making. Sci. Technol. Prog. Policy 2018, 35, 1-7.

23. Shan, W.; Zhang, C.; Wang, J. Internal Social Network, Absorptive Capacity and Innovation: Evidence from New Ventures in China. Sustainability 2018, 10, 1094. [CrossRef]

24. Cumming, D.; Johan, S. Information Asymmetries, Agency Costs and Venture Capital Exit Outcomes. Ventur. Cap. 2008, 10, 197-231. [CrossRef]

25. Bruggeman, J.; Carnabuci, G.; Vermeulen, I. A Note on Structural Holes Theory and Niche Overlap. Soc. Netw. 2003, 25, 97-101. [CrossRef] 
26. Weber, C. Corporate Venture Capitalists with a Bird'S-Eye View- a Dynamic Social Network Perspective. Schmalenbach Bus. Rev. 2009, 61, 195-224. [CrossRef]

27. Shi, L.; Dang, X.; Han, J. Venture Capital Firm Network Centrality, Knowledge Specialization and Investment Performance. Sci. Technol. Prog. Policy 2016, 33, 136-141.

28. Hochberg, Y.V.; Ljungqvist, A.; Lu, Y. Whom You Know Matters: Venture Capital Networks and Investment Performance. J. Financ. 2007, 62, 251-301. [CrossRef]

29. Ozmel, U.; Robinson, D.T.; Stuart, T.E. Strategic Alliances, Venture Capital, and Exit Decisions in Early Stage High-tech Firms. J. Financ. Econ. 2013, 107, 655-670. [CrossRef]

30. Lux, T. Herd Behaviour, Bubbles and Crashes. Econ. J. 1995, 105, 881-896. [CrossRef]

31. Zhao, F.; Wang, T.; Zhang, L. An Empirical Study on the Effect of Diversification Strategy on Firm Performance. China Soft Sci. 2012, 11, 111-122.

32. Megginson, W.L.; Weiss, K.A. Venture capitalist certification in initial public offerings. J. Financ. 1991, 46, 879-903. [CrossRef]

33. Yang, Z.; Liu, S. Study on the Foreign Shareholders Held Influencing on the Risk of Chinese Stock Market. Soft Sci. 2013, 27, 75-79, 92.

(C) 2020 by the authors. Licensee MDPI, Basel, Switzerland. This article is an open access article distributed under the terms and conditions of the Creative Commons Attribution (CC BY) license (http://creativecommons.org/licenses/by/4.0/). 